\title{
Direct reprogramming of adult somatic cells toward adventitious root formation in forest tree species: the effect of the juvenile-adult transition
}

\section{Carmen Díaz-Sala*}

Department of Life Sciences, University of Alcalá, Alcalá de Henares, Spain

\section{Edited by:}

José Manuel Pérez-Pérez,

Universidad Miguel Hernandez de

Elche, Spain

Reviewed by:

Joseph F. Petolino, Dow

AgroSciences, USA

Einat Sadot, Volcani Center, Israel

*Correspondence:

Carmen Díaz-Sala, Department of Life Sciences, University of Alcalá,

Carretera Madrid-Barcelona Km

33.600, 28805 Alcalá de Henares,

Madrid, Spain

e-mail: carmen.diazsala@uah.es
Cellular plasticity refers, among others, to the capability of differentiated cells to switch the differentiation process and acquire new fates. One way by which plant cell plasticity is manifested is through de novo regeneration of organs from somatic differentiated cells in an ectopic location. However, switching the developmental program of adult cells prior to organ regeneration is difficult in many plant species, especially in forest tree species. In these species, a decline in the capacity to regenerate shoots, roots, or embryos from somatic differentiated cells is associated with tree age and maturation. The decline in the ability to form adventitious roots from stem cuttings is one of the most dramatic effects of maturation, and has been the subject of investigations on the basic nature of the process. Cell fate switches, both in plants and animals, are characterized by remarkable changes in the pattern of gene expression, as cells switch from the characteristic expression pattern of a somatic cell to a new one directing a new developmental pathway. Therefore, determining the way by which cells reset their gene expression pattern is crucial to understand cellular plasticity. The presence of specific cellular signaling pathways or tissue-specific factors underlying the establishment, maintenance, and redirection of gene expression patterns in the tissues involved in adventitious root formation could be crucial for cell fate switch and for the control of age-dependent cellular plasticity.

Keywords: age, auxin gradients, cell fate, developmental plasticity, epigenetics, gene expression, maturation, pluripotency

\section{DE NOVO REGENERATION IN PLANTS}

Plant tissues have extensive regenerative capacity, and entire plants can be developed from single cells or small cuttings (Xu and Huang, 2014). In plants, the possibility to regenerate roots, shoots, or embryos directly from cells other than root or shoot meristems, lateral root initials, or zygotes has been known for years and has been exploited in horticulture, agriculture, and forestry (Vasil, 2008). However, little is known about the mechanisms that enable a somatic differentiated cell to switch its fate into a pluripotent or totipotent cell that can develop a root, shoot or embryo, or repair damaged tissues.

Dedifferentiation, i.e., the loss of a specialized form or condition previously acquired during development that can be manifested by the loss of morphological cell identity or by the re-entry into the cell-cycle of non-dividing cells, has been a central concept in plant regeneration. Although apparent dedifferentiation and re-specification of cells seems to occur (Birnbaum and Sánchez Alvarado, 2008), whether acquisition of competence to regenerate organs occurs, as in animal cells, through dedifferentiation, via transdifferentiation or by the use of pre-existent totipotent or pluripotent cells in adult tissues remains unknown (Stocum and Zupane, 2008).

Recently, various publications on the mechanisms of de novo regeneration in non-recalcitrant model plant species demonstrate that there are many possible pathways and strategies for regeneration (Sena and Birnbaum, 2010). Callus formation has been considered a cell dedifferentiation process. However, Sugimoto et al. (2010) described that callus formation from specific Arabidopsis tissues involves a special population of starting pericycle-like cells distributed throughout the entire body of the plant. The process of callus formation is induced via a root developmental pathway, confirming that callus induction could not simply be the result of a dedifferentiation process. The mechanisms of induction and repression of callus formation are unknown. Several key regulators of auxin and cytokinin signaling pathways, as well as the involvement of intrinsic programs of cell development, and their interaction, function during callus formation (Chen et al., 2012; Ikeuchi et al., 2013).

If callus cells do not seem to have an undifferentiated state, and might have a root identity, the induction of shoots from callus through the application of cytokinins might involve the switch of one cell type into another, a process called transdifferentiation. In plant regeneration, transdifferentiation appears to be the process of regeneration in other cases, such as the plant root tip regeneration (Sena et al., 2009) or the direct origin of shoots from the hypocotyl and the root xylem pericycle cells, at sites normally involved in lateral root meristem formation, upon direct culture on a cytokinin-rich medium (Atta et al., 2009). The conversion of early lateral root meristem-like structures, induced upon direct culture in an auxin-rich medium, into shoots after treatments with 
cytokinins could be also considered a transdifferentiation process (Atta et al., 2009). These results demonstrate that xylem pericycle and pericycle-like cells, which are distributed throughout the entire body along the vasculature, could be pluripotent cells that directly originate the different morphogenic programs of callus, roots or shoots, depending on the stimulus in the culture medium. De Almeida et al. (2012) have described that pre-procambial cells can also act as niches for pluripotent and totipotent stem-like cells that are responsive to the auxin/cytokinin ratio resulting in de novo organogenic or embryogenic programs in the shoot apex of peach palm.

The molecular mechanisms underlying plant cell pluripotency of somatic differentiated cells are unknown. The capacity to recruit meristem or embryonic programs in response to a specific stimulus seems to be a key factor for switching cell fate into different developmental programs. Genes reported to have roles in maintaining stem cells or participating in embryonic programs, such as WUSCHEL (WUS), WUSCHEL-RELATED HOMEOBOX (WOX), SHOOTMERISTEMLESS (STM) or LEAFY COTYLEDON (LEC), and the relevance of auxin and cytokinin signaling pathways in the regulation of key genes involved in the organization of stem cell niches have a role in de novo regeneration of Arabidopsis thaliana, Brassica napus, Medicago truncatula, or Gossypium hirsutum (Gordon et al., 2007; Chen etal., 2009; Kakani et al., 2009; Ledwon and Gaj, 2009; Su etal., 2009; Cheng etal., 2010; Elhiti et al., 2010; Elhiti and Stasolla, 2011; Yang etal., 2012; Feeney et al., 2013; Liu et al., 2014). In addition, other transcription factors with known function in meristem activity and stem cell maintenance, such as GIBBERELLIC-ACID INSENSITIVE, REPRESSOR of GAI and SCARECROW (GRAS) or WOUND INDUCED DEDIFFERENTIATION1 (WIND) families were also related to cell reprogramming (Chupeau et al., 2013). Receptor-like kinase genes have been involved in the pluripotent condition leading to somatic embryogenesis, organogenesis and xylogenesis in vitro in Cyclamen persicum Mill (Savona etal., 2012). Many species of the genus Kalanchoë develop plantlets on the leaf margins. Asexual reproduction of these species involves genes related to embryonic development, such as $L E C$, in response to inductive signals in the leaves (Garces et al., 2007, 2014).

\section{RECALCITRANCE FOR DE NOVO REGENERATION IN FOREST TREE SPECIES. EFFECT OF AGE AND MATURATION}

Recalcitrance for organogenesis or somatic embryogenesis is a major limitation in the clonal propagation of many woody species, especially forest tree species such as conifers. Endogenous and environmental factors such as genotype, tissue and timing of excision, phenology, tree maturation, light or temperature could be limiting for regeneration in these species (Bonga et al., 2010; Rutledge et al., 2013). Among them, tree maturation is one of the major limiting factors; it is well known that regeneration efficiency is much higher in tissues at earlier stages of development (George et al., 2008). Maturation is an age-related developmental process described in several plants which affects morphology and growth rate and is associated with the onset of flowering (Poethig, 2003). In trees, maturation has dramatic effects on a number of morphological and physiological traits, such as shoot height and diameter, foliar attributes, stomatal conductance, phostosynthesis, and respiration rates (Day et al., 2002; Day and Greenwood, 2011). Adventitious rooting is an essential but sometimes rate-limiting step in the clonal multiplication of elite tree germplasm, because the ability to form roots declines rapidly with age. Therefore, the decline in the ability to form adventitious roots from stem cuttings at maturation limits the success of vegetative propagation of adult individuals from tree species (Díaz-Sala et al., 1996; Day et al., 2002; Abarca and Díaz-Sala, 2009a). The threshold age at which this decrease occurs, and the rate of decline may vary among species and even among clones within species. In general, the bulk of evidence indicates that the ease in rooting of juvenile tissues of some trees is more a function of the ease in forming root initials than of the physical restriction for root emergence (Díaz-Sala et al., 1996; Goldfarb et al., 1998). This raises the question of whether trees maintain certain cells, which have not been determined to develop a specific organ, outside the meristematic region in a specific differentiated state that can easily access pluripotent or totipotent properties at a mature stage of development, and whether callus cells lose the differentiated characteristics of the tissue from which they originated as described for herbaceous plants (Sugimoto et al., 2010). Calli include a population of cells with several degrees of differentiation; and callus also displays several degrees of regeneration capacity. In vitro tissue culturists have experienced the diversity of callus morphology and their regeneration capacity. It is also known that callus cells from adult tissues of woody species maintain the committed state of the progenitor cells showing a lower proliferation rate and lower regeneration capacity than those induced from juvenile tissues (Hackett et al., 1990). In addition, for specific adventitious programs such as somatic embryogenesis, a highly genotype-dependent program, the induction of somatic embryos is difficult from tissues older than the zygotic embryo, often from the inmature state (Bonga et al., 2010). Therefore, the effect of the developmental transitions and the age of the tissues on the capacity of cells to be reprogrammed, and to induce a new developmental program in trees poses a major question. The loss of regeneration capacity associated with the juvenile-adult transition makes forest tree species representative and reliable systems to study how cell fate becomes fixed during development and how plant cells can manage to retain developmental plasticity.

\section{ADVENTITIOUS ROOT FORMATION IN FOREST TREE SPECIES}

Adventitious root formation is a post-embryonic organogenic process in which roots are induced, in general, from determined, or differentiated cells that have not been specified to develop a root at positions where they do not normally occur during development. De novo induction of organs or whole organisms in an ectopic location, such as the appearance of roots from stem cuttings in plants, involve the induction of meristems from adult somatic cells that are not determined to originate a meristem in normal development. Adventitious root formation is usually induced in stem cuttings, which experience a stimulus, such as wounding, although it can also take place in intact plants in some species (Abarca and Díaz-Sala, 2009a). For most forest tree species, cambial cells or vascular parenchyma cells are the main progenitor cells to induce adventitious roots directly, i.e., without the induction of callus 
(Díaz-Sala et al., 1996; Ballester et al., 1999; De Klerk et al., 1999; Vidal et al., 2003; Rigal et al., 2012). These cells lose competence for de novo regeneration of roots with the age and maturation of the tree. Therefore, the different regeneration capacity of similar cell types at different developmental stages, and the absence of callus formation during the direct regeneration process, offers the opportunity to study both how cell fate becomes fixed during development, as well as a direct developmental switch, without passing through a developmentally non-identified callus cell.

While auxins are required to induce roots (Díaz-Sala et al., 1996; Goldfarb et al., 1998; Ballester et al., 1999; Fett-Neto et al., 2001), other factors also affect rooting (Abarca and Díaz-Sala, 2009a; Legué et al., 2014). The pronounced decline in the rooting potential of mature cuttings or mature tissue culture explants is paralleled by differences in the rooting response to auxin (DíazSala et al., 1996; Greenwood et al., 2001). Although easy- and difficult-rooting lines from Eucalyptus globulus showed different levels of indole-3-acetic acid, auxins do not seem to be the limiting factor for the maturation-related decline to form adventitious roots in Pinus, Castanea, or Quercus species (Díaz-Sala et al., 1996; Ballester et al., 1999; Vidal et al., 2003). The initial hypothesis that non-competent mature tissues would not respond, or would respond more slowly, to auxin than competent tissues in terms of reorganization and cell division, was rejected in pine by Díaz-Sala et al. (1996) and Greenwood et al. (2001). Rootingcompetent and non-competent cells respond similarly during the early stages of root induction; both types of cells re-enter the cell division cycle, but only cells at specific locations in juvenile tissues form an adventitious root meristem. This result added to the growing body of evidence that suggests that the loss of ability of mature tissues to form adventitious roots in response to auxin is not due to the lack of initial auxin responses (Díaz-Sala et al., 1996; Ballester et al., 1999; Greenwood et al., 2001). Therefore, in these cases, auxin seems to be a non-specific trigger of specific pre-set cell reaction patterns, and the lack of rooting ability could be a result of an intrinsic incapacity of cells to organize into a root meristem in response to auxin, perhaps due to the suppression of gene expression needed for cells to enter the root formation pathway during the earliest stages of adventitious root formation (Hutchison etal., 1999; Gil et al., 2003; Busov et al., 2004). The mechanisms underlying maturation-related decline of rooting ability, and other maturational changes, in forest tree species are unknown, but appear to be temporally regulated and synchronized by an array of signal transduction pathways that operate either independently or interacting with other signaling pathways, dependent on the development and very difficult to reverse (Day et al., 2002). According to Greenwood et al. (2001), rooting competence is ultimately a function of differential expression of genes affecting all phases of root meristem formation. Given that no specific auxin signal transduction pathways have been characterized in terms of rooting, elucidation of gene expression programs affecting rooting would be a worthwhile avenue of exploration.

\section{GENE REGULATION AND ADVENTITIOUS ROOT FORMATION IN FOREST TREE SPECIES}

The cellular processes underlying adventitious root formation are complex, and involve cell reorganization, induction of cell divisions, the organization of a root primordium and root development and emergence (Abarca and Díaz-Sala, 2009a; Legué et al., 2014). However, the knowledge of the physiological and cellular changes involved in the rooting process does not necessarily lead to an understanding of the regulatory mechanisms involved. Reprogramming a differentiation pathway implies changes in cell division and patterns of cell differentiation requiring a change in the balance of the expression of hundreds of genes. The most promising approach to investigate the temporal distribution of specifically regulated transcripts in adventitious root development is the use of techniques directly detecting genes differentially expressed during different stages of the rooting process in different tissues (Abarca and Díaz-Sala, 2009a). In general, simple and synchronized experimental systems have been exploited for this purpose (Díaz-Sala et al., 1996; Hutchison et al., 1999; Lindroth et al., 2001; Brinker et al., 2004; Sánchez et al., 2007; Solé et al., 2008; Abu-Abied et al., 2012; Rigal et al., 2012). Different approaches have been followed to identify genes involved in adventitious root formation, from classical procedures of molecular biology (Goldfarb et al., 2003) to the sequencing of expression sequence tag (EST) collections enriched in cDNAs expressed in rooting-competent cuttings under inductive conditions, such as those obtained by differential displays of mRNAs (Díaz-Sala et al., 1997; Greenwood et al., 1997; Hutchison et al., 1999) or subtractive hybridization (Abarca and Díaz-Sala, 2009a). The sequencing of various tree genomes (Tuskan et al., 2006; Mackay et al., 2012; Petroli et al., 2012; Nystedt et al., 2013) has led to the development of high-throughput technologies used to follow the changes of expression of thousands of genes simultaneously. Global gene expression using microarray technology has been used to identify genes and pathways associated with adventitious rooting. Transcriptome analysis in stem cuttings revealed significant shifts during the very earliest stages of the process (Ramírez-Carvajal et al., 2009; Ramirez-Carvajal and Davis, 2010; Abu-Abied et al., 2012; Rigal et al., 2012), at the reorganization stage but before the onset of divisions leading to the formation of an adventitious root meristem (Sánchez et al., 2007; Solé et al., 2008; Vielba et al., 2011). In addition, the sequencing of tree genomes has also allowed the in silico identification and characterization of several multigene families.

\section{PLANT GROWTH REGULATORS AND OTHER SIGNALS}

Plant growth regulators, mostly auxins, and other factors are crucial for root induction (Abarca and Díaz-Sala, 2009a; Negishi et al., 2011; Da Costa etal., 2013; Legué et al., 2014; Su and Zhang, 2014). Significant remodeling in gene networks involved in auxin, gibberellin-, cytokinin- or ethylene-responsive genes, as well as genes that have been implicated in signaling such as the Ser/Thr protein kinases were detected during the initial stages in competent cuttings (Goldfarb et al., 2003; Ramirez-Carvajal and Davis, 2010; Rigal et al., 2012). Ramírez-Carvajal et al. (2009) have described that a cytokinin type-B response regulator, $P t R R 13$, acts downstream of cytokinin to repress adventitious root formation in intact plants, and that reduced cytokinin signaling after shoot excision enables coordinated expression of ethylene, auxin, and vascularization pathways leading to adventitious root development in poplar. 
De novo organ formation and cell specification are processes involving rearragements of tissue polarity, whereby the temporal and spatial distribution of auxin is a very important factor determining tissue polarization and patterning (Xu et al., 2006). Asymmetric auxin localization was detected in rooting-competent cambial tissues of Monterey pine after excision during the initial stages of the root induction process, before the onset of cell divisions, and at root meristem formation; however, no asymmetric auxin distribution was observed in the cambial cells of non-competent mature cuttings (Abarca etal., 2011; Brunoni et al., 2014). This result could indicate that rooting-competent tissues could retain a certain intrinsic capacity to accumulate auxin, perhaps by endogenous redistribution of PIN proteins (Sena et al., 2009). Auxin distribution largely depends on the dynamic expression and subcellular localization of the PIN auxin-carrier proteins (Friml, 2010). However, PIN activity can be modulated by other endogenous signals to trigger developmental decisions. Gibberellin treatment negatively affects the number of adventitious roots produced by wild-type poplar and hybrid aspen cuttings (Busov et al., 2006; Mauriat et al., 2014). Gibberellins appear to act by perturbing polar auxin transport, in particular auxin efflux in hybrid aspen, and both efflux and influx carriers in Arabidopsis (Mauriat et al., 2014). Alternatively, other signals, such as the stress originated by wounding (Grafi et al., 2011; Da Costa et al., 2013), could initiate regeneration by triggering cell fate or other local changes. No differences in the wounding stress response were observed between competent and non-competent cuttings (Greenwood et al., 1997). The level of mRNAs of genes that were not directly involved in root meristem organization, but were induced by other factors involved in the process such as the wounding-induced PHENYLALANINE-AMMONIA-LYASE $(P A L)$, was not dependent on the presence of exogenous auxin and was similar in competent and non-competent cuttings. These data suggest that the increased $P A L$ level during the earliest stages of adventitious root formation does not seem to be a function of the rooting capacity of tissues, but rather a non-specific response to wounding. A higher transient increase of nitric oxide and a nitrate reductase gene expression were measured in juvenile cuttings of E. grandis (Abu-Abied et al., 2012) that may also affect auxin signaling. Regulatory functions via protein phosphorylation affecting proteins involved in rejuvenation of Sequoia and in regeneration have also been described (Chang et al., 2010; Wang et al., 2014).

\section{THE CONTINUUM OF CELL WALL, PLASMA MEMBRANE, CYTOSKELETON, AND CELL DIVISION}

Gene expression analysis during the initial stages of adventitious root formation, at the cell reorganization stage, showed that genes coding for proteins involved in cell wall remodeling were the most highly expressed. EXPANSIN genes were induced in non-growing tissues before the resumption of cell division resulting in an adventitious root meristem in loblolly pine (Hutchison et al., 1999). Similarly, Rigal et al. (2012) demonstrated that the patterns of transcript abundance of several glycoside hydrolases, pectate lyases, pectin esterases, and expansins changed at this stage in poplar. Cytoskeleton genes, such as ACTIN, were upregulated in competent cutings during the initial stages of adventitious rooting in loblolly pine and E. grandis (Greenwood et al., 1997; Szwerdszarf et al., 2011). A protein with GTP-binding motifs, involved in regulating cell wall biosynthesis and actin organization, was associated with adventitious root formation and other processes requiring directional cell expansion, such as lateral root formation or the growth of root hairs, in poplar (Xu et al., 2012). In addition to the inductive effects of auxin, the effect of the RGD peptides is a necessary condition for rooting of hypocotyls from de-rooted adult plants of Arabidopsis (DíazSala et al., 2002). These results provide support for the hypothesis that cell wall-plasma membrane-cytoskeleton interactions of specific cells could be involved in the rooting capacity of adult plants, perhaps by the stabilization of differentiation, cell division, and morphogenesis. Roycewicz and Malamy (2014) have suggested that intrinsic pathways that alter cell walls may be sufficient to promote lateral root formation by facilitating the separation of the cells overlying the lateral root primordium.The expression of the cell-cycle genes CYCLIN-DEPENDENT KINASE (PtCDK; Greenwood et al., 1997) and PSTAIRE CDC2 (PcCDC2; Lindroth et al., 2001) from pine suggests a role of PcCDC2 in a premitotic stage and its expression could be an indicator of competence in which appropriate cells are capable of responding to auxin for adventitious rooting. Cell-cycle genes have been associated with cell competence and cell reprogramming during regeneration (Boucheron et al., 2002; Ishikawa et al., 2011). However, PtCDK does not seem to be related to the maturation-related loss of adventitious root formation. Perhaps re-entering to a formative cell division pathway in competent tissues, as opposed to proliferative cell division in non-competent tissues, requires other checkpoints.

\section{MERISTEM ACTIVITY AND CELL FATE DETERMINATION}

Among the transcripts that show significant changes in expression at the reorganization stage of adventitious root formation, several transcription factors involved in embryonic programs and cell fate determination in meristems have been identified (Brinker et al., 2004; Sánchez et al., 2007; Ricci et al., 2008; Solé et al., 2008; Abarca and Díaz-Sala, 2009a,b; Vielba et al., 2011; Rigal et al., 2012; Trupiano et al., 2013; Brunoni et al., 2014). In poplar, the most highly modulated transcription factor group was the AP2/ERF family (Rigal et al., 2012). The AP2 subfamily is known to be involved in maintaining cells in a meristematic and/or division-competent state (Nole-Wilson et al., 2005). Among the 13 ANT-LIKE genes in poplar, several members of the ANT-AIL group were highly expressed at the initial stages of adventitious root formation, especially PtAIL1. Functional analysis clearly indicated that PtAIL1 is a positive regulator of adventitious rooting that acts by promoting the formation of root primordia. Using activation tagging in poplar, Trupiano et al. (2013) have identified a gene encoding a transcription factor of the AP2/ERF family of unknown function (PtaERF003) that has a positive effect on both adventitious and lateral root proliferation. The function of PtaERF003 is linked to the auxin signal transduction pathway, as suggested by the rapid induction and accentuated phenotypes of the transgenic plants in presence of the hormone.

In conifers, Brinker et al. (2004) investigated the gene expression pattern during adventitious root formation of lodgepole pine. 
Interestingly, a cell-fate meristem regulatory gene, ZWILLE-LIKE, was found during the earliest stages, suggesting a role in the initiation of the root development process. Similarly, Sánchez et al. (2007) and Solé etal. (2008) described a SCARECROWLIKE gene in Monterey pine (PrSCL1) and in chestnut (CsSCL1), and a SHORT-ROOT gene in Monterey pine (PrSHR) that may play a role during the earliest stages of adventitious root induction. In Arabidopsis and other plant species, such as rice or maize, the establishment of an embryonic root meristem involves members of the GRAS family of putative transcription factors which includes SCARECROW (SCR), SCARECROW-LIKE (SCL), and SHORT-ROOT (SHR) proteins (Helariutta et al., 2000; Sabatini et al., 2004). PrSCL1, CsSCL1, and PrSHR were predominantly expressed in roots, root primordia and in the cambial region of competent cuttings. Localized and transient increases of mRNA levels were observed in the cambial region and rootingcompetent cells within the initial stages of the adventitious rooting process before the onset of cell divisions. The expression pattern of PrSCL1 and PrSHR overlapped; PrSCL1 was induced in the presence of the exogenous auxin needed for cuttings to root, whereas $\mathrm{PrSHR}$ induction was not dependent on exogenous auxin. These results suggest that auxin-dependent and auxin-independent pathways could be associated with the rooting capacity of tissues, and that GRAS genes may play a role during the earliest stages of adventitious rooting in pine (Sánchez et al., 2007; Solé et al., 2008). The CsSCL1 signal was more diffuse and evenly distributed through the phloem and parenchyma in non-competent mature cuttings (Vielba et al., 2011). GRAS genes seem to also be involved in the rooting pathway associated with the enhancement of rooting by diphenylureas in Monterey pine (Ricci et al., 2008; Brunoni et al., 2014). The sequencing of conifer genomes (Mackay et al., 2012; Nystedt et al., 2013) has also led to the in silico identification and characterization of multigene families. Expression analysis of additional members of the pine GRAS family showed that the expression of specific members of the multigene family could be involved in complex transcript regulatory networks associated with tissue- and/or auxin-dependent pathways in root competent tissues (Abarca et al., 2011).

\section{COMPETENCE AND REPATTERNING: SEARCHING FOR INDETERMINANCY GENES}

Unraveling the early events leading to the acquisition of cell pluripotency is a fundamental issue to understand cellular plasticity. There are two separate phenomena that appear to be basic steps in plant regeneration: (1) acquisition of competence to regenerate through dedifferentiation, transdifferentiation or by use of pre-existing totipotent cells; and (2) repatterning of regenerating tissues. Searching for master regulatory genes is essential in the future of adult cell fate switch studies, but searching for master rechanneling genes, which could be among the earliest events associated with fate switching by re-directing the differentiation state, is equally important (Abarca and Díaz-Sala, $2009 b$ ). In addition, the restriction of the reprogramming potential could be related to the presence of signals in the tissues that retain a physiological or developmental memory. Chromatin status and epigenetic mechanisms resulting in a specific nuclear architecture could be involved in the control of cellular plasticity (Bräutigam et al., 2013). Epigenetic regulation of vegetative phase change, dedifferentiation, and adventitious root formation has been described (Wang et al., 2011; Vining et al., 2013; You et al., 2014). In addition, epigenetically repressed embryonic programs could be presumably involved in callus repression and regeneration in post-embryonic tissues (Chen et al., 2012; Ikeuchi et al., 2013). The large-scale transcript profiles of plantlets and dedifferentiated protoplast-derived cells from Arabidopsis indicate that the epigenetic status of protoplast-derived cells differs from the well-established cultures, with protoplast-derived cells exhibiting changes in transposon reactivation and chromatinassociated genes (Chupeau et al., 2013). The genome sequencing of forest tree species and the development of transcriptomic tools, including next generation sequencing technologies, will allow a large-scale comparative analysis of transcriptomes of tissues with different degrees of determination and competence, facilitating the identification of new genes involved in cellular plasticity.

\section{ACKNOWLEDGMENTS}

This work has been supported by grants from the Spanish Ministry of Economy and Competitiveness (AGL2011-30462, AGL200805105-C02-01, Acciones Integradas España-Italia HI 2007-0150 to Carmen Díaz-Sala) and from the Regional Government of Madrid (S2009AMB-1668 REGENFOR-CM to Carmen DíazSala). We would like to thank P. H. Serrot for her comments on the manuscript.

\section{REFERENCES}

Abarca, D., and Díaz-Sala, C. (2009a). "Adventitious root formation in conifers," in Adventitious Root Formation of Forest Trees and Horticultural Plants - From Genes to Applications, eds K. Niemi and C. Scagel (India: Research Signpost Publishers), 227-257.

Abarca, D., and Díaz-Sala, C. (2009b). Reprogramming adult cells during organ regeneration in forest species. Plant Signal. Behav. 4, 1-3. doi: 10.4161/psb.4. 8.9238

Abarca, D., Pizarro, A., Del Amo, A., and Díaz-Sala, C. (2011). Screening of genes associated with early stages of adventitious root formation from progenitor adult cells of Pine. BMC Proc. 5(Suppl. 7):P133. doi: 10.1186/1753-6561-5-S7-P133

Abu-Abied, M., Szwerdszarf, D., Morde-Haev, I., Levy, A., Rogovoy, O., Belausov, E., et al. (2012). Microarray analysis revealed upregulation of nitrate reductase in juvenile cuttings of Eucalyptus grandis, which correlated with increased nitric oxide production and adventitious root formation. Plant J. 71, 787-799. doi: 10.1111/j.1365-313X.2012.05032.x

Atta, R., Laurens, L., Boucheron-Dubuisson, E., Guivarc'h, A., Carnero, E., Giraudat-Pautot, V., et al. (2009). Pluripotency of Arabidopsis xylem pericycle underlies shoot regeneration from root and hypocotyl explants grown in vitro. Plant J. 57, 626-644. doi: 10.1111/j.1365-313X.2008.03715.x

Ballester, A., San-José, M. C., Vidal, N., Fernández-Lorenzo, J. L., and Vieitez, A. M. (1999). Anatomical and biochemical events during in vitro rooting of microcuttings from juvenile and mature phases of chestnut. Ann. Bot. 83, 619629. doi: 10.1006/anbo. 1999.0865

Birnbaum, K. D., and Sánchez Alvarado, A. (2008). Slicing across kingdoms: regeneration in plants and animals. Cell 132, 697-710. doi: 10.1016/j.cell.2008. 01.040

Bonga, J. M., Klimaszewska, K. K., and von Aderkas, P. (2010). Recalcitrance in clonal propagation, in particular of conifers. Plant Cell Tissue Organ Cult. 100, 241-254. doi: 10.1007/s11240-009-9647-2

Boucheron, E., Guivarc'h, A., Azmi, A., Dewitte, W., Van Onckelen, H., and Chriqui, D. (2002). Competency of Nicotiana tabacum L. stem tissues to dedifferentiate is associated with differential levels of cell cycle gene expression and endogenous cytokinins. Planta 215, 267-278. doi: 10.1007/s00425-002-0761-1 
Bräutigam, K., Vining, K. J., Lafon-Placette, C., Fossdal, C. G., Mirouze, M., Gutierrez Marcos, J., et al. (2013). Epigenetic regulation of adaptive responses of forest tree species to the environment. Ecol. Evol. 3, 399-415. doi: 10.1002/ ece3.461

Brinker, M., van Zyl, L., Liu, W., Craig, D., Sederoff, R. R., Clapham, D. H., et al. (2004). Mycroarrays analysis of gene expression during adventitious root development in Pinus contorta. Plant Physiol. 135, 1526-1539. doi: 10.1104/pp.103. 032235

Brunoni, F., Rolli, E., Dramis, L., Incerti, M., Abarca, D., Pizarro, A., et al. (2014). Adventitious rooting adjuvant activity of 1,3-di(benzo[d] oxazol-5-yl) urea and 1,3-di(benzo[d] oxazol-6-yl)urea: new insights and perspectives. Plant Cell Tissue Organ Cult. 118, 111-124. doi: 10.1007/s11240-014-0466-8

Busov, V. B., Johannes, R. W., Whetten, R., Sederoff, R. R., Spiker, S., Lanz-García, C., et al. (2004). An auxin-inducible gene from loblolly pine (Pinus taeda L.) is differentially expressed in mature and juvenile phase shoots and and encodes a putative transmembrane protein. Planta 218, 916-927. doi: 10.1007/s00425-0031175-4

Busov, V., Meilan, R., Pearce, D. W., Rood, S. B., Ma, C., Tschaplinski, T. J., et al. (2006). Transgenic modification of gai or rgll causes dwarfing and alters gibberellins, root growth, and metabolite profile in Populus. Planta 224, 288-299. doi: 10.1007/s00425-005-0213-9

Chang, I. F., Chen, P. J., Shen, C. H., Hsieh, T. J., Hsu, Y. W., Huang, B. L., et al. (2010). Proteomic profiling of proteins associated with the rejuvenation of Sequoia sempervirens (D. Don) Endl. Proteome Sci. 8:64. doi: 10.1186/14775956-8-64

Chen, C. C., Fu, S. F., Lee, Y. E., Lin, C. Y., Lin, W. C., and Huang, H. J. (2012). Transcriptome analysis of age-related gain of callus-forming capacity in Arabidopsis hypocotyls. Plant Cell Physiol. 53, 1457-1469. doi: 10.1093/pcp/pcs090

Cheng, Z. J., Zhu, S. S., Gao, X. Q., and Zhang, X. S. (2010). Cytokinin and auxin regulates WUS induction and inflorescence regeneration in vitro in Arabidopsis. Plant Cell Rep. 29, 927-933. doi: 10.1007/s00299-010-0879-8

Chen, S. K., Kurdyukov, S., Kereszt, A. Wang, X. D., Gressho, P. M., and Rose, R. J. (2009). The association of homeobox gene expression with stem cell formation and morphogenesis in cultured Medicago truncatula. Planta 230, 827-840. doi: 10.1007/s00425-009-0988-1

Chupeau, M. C., Granier, F., Pichon, O., Renou, J. P., Gaudin, V., and Chupeau, Y. (2013). Characterization of the early events leading to totipotency in an Arabidopsis protoplast liquid culture by temporal transcript profiling. Plant Cell 25, 2444-2463. doi: 10.1105/tpc.113.109538

Da Costa, C. T., de Almeida, M. R., Ruedell, C. M., Schwambach, J., Maraschin, F. S., and Fett-Neto, A. G. (2013). When stress and development go hand in hand: main hormonal controls of adventitious rooting in cuttings. Front. Plant Sci. 4:133. doi: $10.3389 /$ fpls.2013.00133

Day, M. E., and Greenwood, M. S. (2011). "Regulation of ontogeny in temperate conifers," in Size- and Age-Related Changes in Tree Structure and Function, Tree Physiology, Vol. 4, ed. F. C. Meinzer (Houten: Springer Science+Business Media B.V.), 91-119.

Day, M. E., Greenwood, M. S., and Díaz-Sala, C. (2002). Age-and size-related trends in woody plant shoot development: regulatory pathways. Tree Physiol. 22, 507-513. doi: 10.1093/treephys/22.8.507

De Almeida, M., Vieira de Almeida, C., Mendes Graner, E., Ebling Brondani, G., and Fiori de Abreu-Tarazi, M. (2012). Pre-procambial cells are niches for pluripotent and totipotent stem-like cells for organogenesis and somatic embryogenesis in the peach palm: a histological study. Plant Cell Rep. 31, 1495-1515. doi: 10.1007/s00299-012-1264-6

De Klerk, G. J., Van der Krieken, W., and De Jong, J. C. (1999). Review the formation of adventitious roots: new concepts, new possibilities. In Vitro Cell. Dev. Biol. Plant 35, 189-199. doi: 10.1007/s11627-999-0076-z

Díaz-Sala, C., Garrido, G., and Sabater, B. (2002). Age-related loss of rooting capability in Arabidopsis thaliana and its reversal by peptides containing the RGD motif. Physiol. Plant. 114, 601-607. doi: 10.1034/j.1399-3054.2002.1140414.x

Díaz-Sala, C., Hutchison, K. W., Golfbarb, B., and Greenwood, M. S. (1996). Maturation-related loss in rooting competence by loblolly pine stem cuttings: role of polar auxin transport and tissue sensitivity. Physiol. Plant. 97, 481-490. doi: 10.1111/j.1399-3054.1996.tb00507.x

Díaz-Sala, C., Singer, P. B., Greenwood, M. S., and Hutchison, K. W. (1997). "Molecular approaches to maturation-related decline in adventitious rooting ability in loblolly pine (Pinus taeda L.)," in Somatic Cell genetics and Molecular Genetics of
Trees, eds M. R. Ahuja, W. Boerjan, and D. B. Neale (Dordrecht: Kluwer Academic Publishers), 57-61.

Elhiti, M., and Stasolla, C. (2011). Ectopic expression of the Brassica SHOOTMERISTEMLESS attenuates the deleterious effects of the auxin transport inhibitor TIBA on somatic embryo number and morphology. Plant Sci. 180, 383-390. doi: 10.1016/j.plantsci.2010.10.014

Elhiti, M., Tahir, M., Gulden, R. H., Khamiss, K., and Stasolla, C. (2010). Modulation of embryo-forming capacity in culture through the expression of Brassica genes involved in the regulation of the shoot apical meristem. J. Exp. Bot. 61, 4069-4085. doi: 10.1093/jxb/erq222

Feeney, M., Frigerio, L., Cui, Y., and Menassa, R. (2013). Following vegetative to embryonic cellular changes in leaves of Arabidopsis overexpressing LEAFY COTYLEDON. Plant Phys. 162, 1881-1896. doi: 10.1104/pp.113.220996

Fett-Neto, A. G., Fett, J. P., Goulart, L. W. V., Pasquali, G., Termignoni, R. R., and Ferreira, A. G. (2001). Distinct effects of auxin and light on adventi- tious root development in Eucalyptus saligna and Eucalyptus globulus. Tree Physiol. 21, 457-464. doi: 10.1093/treephys/21.7.457

Friml, J. (2010). Subcellular trafficking of PIN auxin efflux carriers in auxin transport. Eur. J. Cell Biol. 89, 231-235. doi: 10.1016/j.ejcb.2009.11.003

Garces, H. M. P., Champagne, C. E. M., Townsley, B. T., Park, S., Malho, R., Pedroso, M. C., et al. (2007). Evolution of asexual reproduction in leaves of the genus Kalanchoë. Proc. Natl. Acad. Sci. U.S.A. 104, 15578-15583. doi: 10.1073/pnas.0704105104

Garces, H. M. P., Koenig, D., Townsley, B. T., Kim, M., and Sinha, N. R. (2014). Truncation of LEAFY COTYLEDON1 protein is required for asexual reproduction in Kalanchoë daigremontiana. Plant Phys. 165, 196-206. doi: 10.1104/pp.114. 237222

George, E. F., Hall, M. A., and De Klerk, G. J. (2008). Plant Propagation by Tissue Culture, Vol. 1, The Background. Basingstoke: Exegetics.

Gil, B., Pastoriza, E., Ballester, A., and Sánchez, C. (2003). Isolation and charcterization of a cDNA from Quercus robur differentially expressed in juvenilelike and mature shoots. Tree Physiol. 23, 633-640. doi: 10.1093/treephys/ 23.9.633

Goldfarb, B., Hackett, W. P., Furnier, G. R., Mohn, C. A., and Plietzsch, A. (1998). Adventitious root initiation in hypocotyl and epicotyl cuttings of eastern white pine seedlings. Physiol. Plant. 102, 513-522. doi: 10.1034/j.13993054.1998.1020405.x

Goldfarb, B., Lanz-García, C., Lian, Z., and Wheten, R. (2003). Aux/IAA gene family is conserved in the gymnosperm lobolly pine (Pinus taeda L.). Tree Physiol. 23, 1181-1192. doi: 10.1093/treephys/23.17.1181

Gordon, S. P., Heisler, M. G., Reddy, G. V., Ohno, C., Das, P., and Meyerowitz, E. M. (2007). Pattern formation during de novo assembly of the Arabidopsis shoot meristem. Development 134, 3539-3548. doi: 10.1242/dev.010298

Grafi, G., Florentin, A., Ransbotyn, V., and Morgenstern, Y. (2011). The stem cell state in plant development and in response to stress. Front. Plant Sci. 2:53. doi: 10.3389/fpls.2011.00053

Greenwood, M. S., Cui, X., and Xu, F. (2001). Response to auxin changes during maturation-related loss of adventitious rooting competence in loblolly pine (Pinus taeda) stem cuttings. Physiol. Plant. 111, 373-380. doi: 10.1034/j.13993054.2001.1110315.x

Greenwood, M. S., Díaz-Sala, C., Singer, P. B., Decker, A., and Hutchison, K. W. (1997). "Differential gene expression during maturation-caused decline in adventitious rooting ability in loblolly pine," in Biology of Root Formation and Development, eds A. Altman and W. Weisel (New York: Plenum Press) 203-207.

Hackett, W. P., Murray, J. R., Woo, H. H., Stapfer, R. E., and Geneve, R. (1990). "Cellular, biochemical and molecular characteristics related to maturation and rejuvenation in woody species," in Plant Aging: Basic and Applied Approaches, eds R. Rodríguez, R. S. Tamés, and D. J. Durzan (New York: Plenum Publishing Corporation), 147-152.

Helariutta, Y., Fukaki, H., Wysocka-Diller, K., Nakajima, J., Jung, G., Sena, M. T., et al. (2000). The SHORT-ROOT gene controls radial patterning of the Arabidopsis root through radial signalling. Cell 101, 555-567. doi: 10.1016/S0092-8674(00) 80865-X

Hutchison, K. W., Singer, P. B., McInnis, S., Díaz-Sala, C., and Greenwood, M. S. (1999). Expansins are conserved in conifers and expressed in hypocotyls in response to exogenous auxin. Plant Physiol. 120, 827-831. doi: $10.1104 /$ pp. 120.3 .827 
Ikeuchi, M., Sugimoto, K., and Iwase, A. (2013). Plant callus: mechanisms of induction and repression. Plant Cell 25, 3159-3173. doi: 10.1105/tpc.113. 116053

Ishikawa, M., Murata, T., Sato, Y., Nishiyama, T., Hiwatashi, Y., Imai, A., et al. (2011). Physcomitrella cyclin-dependent kinase A links cell cycle reactivation to other cellular changes during reprogramming of leaf cells. Plant Cell 23, 2924-2938. doi: 10.1105/tpc.111.088005

Kakani, A., Li, G., and Peng, Z. (2009). Role of AUX1 in the control of organ identity during in vitro organogenesis and in mediating tissue speciWc auxin and cytokinin interaction in Arabidopsis. Planta 229, 645-657. doi: 10.1007/s00425008-0846-6

Ledwon, A., and Gaj, M. D. (2009). LEAFY COTYLEDON2 gene expression and auxin treatmentin relation to embryogenic capacity of Arabidopsis somatic cells. Plant Cell Rep. 28, 1677-1688. doi: 10.1007/s00299-009-0767-2

Legué, V., Rigald, A., and Bhalerao, R. P. (2014). Adventitious root formation in tree species: involvement of transcription factors. Physiol. Plant. 151, 192-198. doi: $10.1111 /$ ppl.12197

Lindroth, A. M., Kvarnheden, A., and von Arnold, S. (2001). Isolation of a PSTAIRE CDC2 cDNA from Pinus contorta and its expression during adventitious root development. Plant Physiol. Biochem. 39, 107-114. doi: 10.1016/S09819428(00)01229-8

Liu, J., Sheng, L., Xu, Y., Li, J., Yang, Z., Huang, H., et al. (2014). WOX11 and 12 are involved in the first-step cell fate transition during de rovo root organogenesis in Arabidopsis. Plant Cell 26, 1081-1093. doi: 10.1105/tpc.114. 122887

Mackay, J., Dean, J. F. D., Plomion, C., Peterson, D. G., Cánovas, F. M., Pavy, N., et al (2012). Towards decoding the conifer giga-genome. Plant Mol. Biol. 80, 555-569. doi: 10.1007/s11103-012-9961-7

Mauriat, M., Petterle, A., Bellini, C., and Moritz, T. (2014). Gibberellins inhibit adventitious rooting in hybrid aspen and Arabidopsis by affecting auxin transport. Plant J. 78, 372-384. doi: 10.1111/tpj.12478

Negishi, N., Oishi, M., and Kawaoka, A. (2011). Chemical screening for promotion of adventitious root formation in Eucalyptus globulus. BMC Proc. 5(Suppl. 7):P139. doi: 10.1186/1753-6561-5-S7-P139

Nole-Wilson, S., Tranby, T. L., and Krizek, B. A. (2005). AINTEGUMENTA-like (AIL) genes are expressed in young tissues and may specify meristematic or division-competent states. Plant Mol. Biol. 57, 613-628. doi: 10.1007/s11103005-0955-6

Nystedt, B., Street, N. R., Wetterbom, A., Zuccolo, A., Lin, Y. C., Scofield, D. G., et al (2013). The Norway spruce genome sequence and conifer genome evolution. Nature 497, 579-584. doi: 10.1038/nature12211

Petroli, C. D., Sansaloni, C. P., Carling, J., Steane, D. A., Vaillancourt, R. E., Myburg, A. A., et al. (2012). Genomic characterization of DArT markers based on highdensity linkage analysis and physical mapping to the Eucalyptus genome. PLoS ONE 7:e44684. doi: 10.1371/journal.pone.0044684

Poethig, S. R. (2003). Phase change and the regulation of developmental timing in plants. Science 301, 334-336. doi: 10.1126/science.1085328

Ramirez-Carvajal, G. A., and Davis, J. M. (2010). Cutting to the base: identifying regulators of adventitious rooting. Plant Signal. Behav. 5, 281-283. doi: 10.4161/psb.5.3.10705

Ramírez-Carvajal, G. A., Morse, A. M., Dervinis, C., and Davis, J. M. (2009). The cytokinin type-B response regulator PtRR13 is a negative regulator of adventitious root development in Populus. Plant Physiol. 150, 759-771. doi: 10.1104/pp.109. 137505

Ricci, A., Rolli, E., Dramis, L., and Díaz-Sala, C. (2008). N'-bis(2,3-methylenedioxyphenyl) urea and $\mathrm{N}, \mathrm{N}^{\prime}$-bis-(3,4-methylenedioxyphenyl)urea enhace adventitious rooting in Pinus and affect the expression of genes induced during adventitious root formation. Plant Sci. 175, 356-363. doi: 10.1016/ j.plantsci.2008.05.009

Rigal, A., Yordanov, Y. S., Perrone, I., Karlberg, A., Tisserant, E., Bellini, C., et al. (2012). The AINTEGUMENTA LIKE1 homeotic transcription factor PtAIL1 controls the formation of adventitious root primordia in poplar. Plant Physiol. 160, 1996-2006. doi: 10.1104/pp.112.204453

Roycewicz, P. S., and Malamy, J. E. (2014). Cell wall properties play an important role in the emergence of lateral root primordia from the parent root. J. Exp. Bot. 65, 2057-2069. doi: 10.1093/jxb/eru056

Rutledge, R. G., Stewart, D., Caron, S., Overton, C., Boyle, B., MacKay, J., et al. (2013). Potential link between biotic defense activation and recalcitrance to induction of somatic embryogenesis in shoot primordia from adult trees of white spruce (Picea glauca). BMC Plant Biol. 13:116. doi: 10.1186/1471-222913-116

Sabatini, S., Heidstra, R., Wildwater, M., and Scheres, B. (2004). SCARECROW is involved in positioning the stem cell niche in the Arabidopsis root meristem. Genes Dev. 17, 354-358. doi: 10.1101/ gad. 252503

Sánchez, C., Vielba, J. M., Ferro, E., Covelo, G., Solé, A., Abarca, D., et al. (2007) Two SCARECROW-LIKE genes are induced in response to exogenous auxin in rooting-competent cuttings of distantly-related forest species. Tree Physiol. 27, 1459-1470. doi: 10.1093/treephys/27.10.1459

Savona, M., Mattioli, R., Nigro, S., Falasca, G., Della Rovere, F., Costantino, P., et al. (2012). Two SERK genes are markers of pluripotency in Cyclamen persicum Mill. J. Exp. Bot. 63, 471-488. doi: 10.1093/jxb/err295

Sena, G., and Birnbaum, K. D. (2010). Built to rebuild: in search of organizing principles in plant regeneration. Curr. Opin. Genet. Dev. 20, 460-465. doi: 10.1016/j.gde.2010.04.011

Sena, G., Wang, X., Liu, H. Y., Hofhuis, H., and Birnbaum, K. D. (2009). Organ regeneration does not require a functional stem cell niche in plants. Nature 457, 1150-1154. doi: 10.1038/nature07597

Solé, A., Sánchez, C., Vielba, J. M., Valladares, S., Abarca, D., and Díaz-Sala, C. (2008). Characterization and expression of a Pinus radiata putative ortholog to the Arabidopsis SHORT-ROOT gene. Tree Physiol. 28, 1629-1639. doi: 10.1093/treephys/28.11.1629

Stocum, D. L., and Zupane, G. K. H. (2008). Stretching the limits: stem cells in regeneration science. Dev. Dyn. 237, 3648-3671. doi: 10.1002/ dvdy. 21774

Sugimoto, K., Jiao, Y., and Meyerowitz, E. M. (2010). Arabidopsis regeneration from multiple tissues occurs via a root development pathway. Dev. Cell 18, 463-471. doi: 10.1016/j.devcel.2010.02.004

Su, Y. H., and Zhang, X. S. (2014). The hormonal control of regeneration in plants. Curr. Top. Dev. Biol. 108, 35-69. doi: 10.1016/B978-0-12-391498-9. 00010-3

Su, Y. H., Zhao, X. Y., Liu, Y. B., Zhang, C. L., O’Neill, S. D., and Zhang, X. S. (2009). Auxin-induced WUS expression is essential for embryonic stem cell renewal during somatic embryogenesis in Arabidopsis. Plant J. 59, 448-460. doi: 10.1111/j.1365-313X.2009.03880.x

Szwerdszarf, D., Abu-Abied, M., Ophir, R., Riov, J., and Sadot, E. (2011). "The juvenile to mature phase change in relation to the potential of adventitious root formation in Eucalyptus grandis," in Abstract Book 6th International Symposium on Root Development: Adventitious, Lateral and Primary Roots, ed. A. DesRochers (Amos: Université du Quebec), 48.

Trupiano, D., Yordanov, Y., Regan, S., Meilan, R., Tschaplinski, T., Scippa, G. S., et al. (2013). Identification, characterization of an AP2/ERF transcription factor that promotes adventitious, lateral root formation in Populus. Planta 238, 271-282. doi: 10.1007/s00425-013-1890-4

Tuskan, G. A., DiFazio, S., Jansson, S., Bohlmann, J., Grigoriev, I., Hellsten, U., et al. (2006). The genome of western black cottonwood, Populus trichocarpa (Torr. \& Gray ex Brayshaw). Science 313, 1596-1603. doi: 10.1126/science. 1128691

Vasil, I. K. (2008). A history of Plant Biotechnology: from the cell theory of Schleiden and Schwann to biotech crops. Plant Cell Rep. 27, 1423-1440. doi: 10.1007/s00299-008-0571-4

Vidal, N., Arellano, G., San-Jose, M. C., Vieitez, A. M., and Ballester, A. (2003). Development stages during the rooting of in vitro-cultured Quercus robur shoots from material of juvenile and mature origin. Tree Physiol. 23, 1247-1254. doi: 10.1093/treephys/23.18.1247

Vielba, J. M., Díaz-Sala, C., Ferro, E., Rico, S., Lamprecht, M., Abarca, D., et al. (2011). CsSCL1 is differentially regulated upon maturation in chestnut microshoots, and is specifically expressed in rooting-competent cells. Tree Physiol. 31, 1152-1160. doi: 10.1093/treephys/tpr086

Vining, K., Pomraning, K. R., Wilhelm, L. J., Ma, C., Pellegrini, M., Di, Y., et al. (2013). Methylome reorganization during in vitro dedifferentiation and regeneration of Populus trichocarpa. BMC Plant Biol. 13:92. doi: 10.1186/14712229-13-92

Wang, J. W., Park, M. Y., Wang, L. J., Koo, Y., Chen, X. Y., Weigel, D., et al. (2011) MiRNA control of vegetative phase change in trees. PLoS Genet. 7:e1002012. doi: 10.1371/journal.pgen.1002012 
Wang, X., Qi, M., Li, J., Ji, Z., Hu, Y., Bao, F., et al. (2014). The phosphoproteome in regenerating protoplasts from Physcomitrella patens protonemata shows changes paralleling postembryonic development in higher plants. J. Exp. Bot. 65, 2093 2106. doi: 10.1093/jxb/eru082

$\mathrm{Xu}$, L., and Huang, H. (2014). Genetic and epigenetic controls of plant regeneration. Curr. Top. Dev. Biol. 108, 1-33. doi: 10.1016/B978-0-12-391498-9. 00009-7

Xu, M., Xie, W., and Huang, M. (2012). Overexpression of PeRHD3 alters the root architecture in Populus. Biochem. Biophys. Res. Commun. 424, 239-244. doi: 10.1016/j.bbrc.2012.06.083

Xu, X., Hofhuis, H., Heidstra, R., Sauer, M., Friml, J., and Scheres, B. (2006). A molecular framework for plant regeneration. Science 311, 385-388. doi: 10.1126/science. 1121790

Yang, X., Zhang, X., Yuan, D., Jin, F., Zhang, Y., and Xu, J. (2012). Transcript profiling reveals complex auxin signalling pathway and transcription regulation involved in dedifferentiation and redifferentiation during somatic embryogenesis in cotton. BMC Plant Biol. 12:110. doi: 10.1186/1471-2229-12-110

You, C. X., Zhao, Q., Wang, X. F., Xie, X. B., Feng, X. M., Zhao, L. L., et al. (2014). A dsRNA-binding protein MdDRB1 associated with miRNA biogenesis modifies adventitious rooting and tree architecture in apple. Plant Biotechnol. J. 12, 183-192. doi: 10.1111/pbi.12125

Conflict of Interest Statement: The author declares that the research was conducted in the absence of any commercial or financial relationships that could be construed as a potential conflict of interest.

Received: 06 May 2014; accepted: 10 June 2014; published online: 07 July 2014.

Citation: Díaz-Sala C (2014) Direct reprogramming of adult somatic cells toward adventitious root formation in forest tree species: the effect of the juvenile-adult transition. Front. Plant Sci. 5:310. doi: 10.3389/fpls.2014.00310

This article was submitted to Plant Genetics and Genomics, a section of the journal Frontiers in Plant Science.

Copyright (c) 2014 Díaz-Sala. This is an open-access article distributed under the terms of the Creative Commons Attribution License (CC BY). The use, distribution or reproduction in other forums is permitted, provided the original author(s) or licensor are credited and that the original publication in this journal is cited, in accordance with accepted academic practice. No use, distribution or reproduction is permitted which does not comply with these terms. 